\begin{tabular}{|l|l|l|l|}
\hline Eiszeitalter $u$. Gegenwart & 35 & $5-6$ & Hannover 1985 \\
\hline
\end{tabular}

\title{
The Comparison of Sea Level Chronologies from the Estuaries of the North Sea (Progress Report)
}

\author{
[Vergleich von Seespiegel-Chronologien \\ aus Ästuaren der Nordsee (Fortschrittsbericht)]
}

\author{
IAN SHENNAN *)
}

Comparison, sea level change, chronologies, Holocene, estuaries. North Sea, Bundesrepublik Deutschland, Jutland, Norway, England, Scotland

This report summarises a number of points discussed in a series of recent published articles and in those papers in various stages of preparation (see list at the end). It is argued that the science of Holocene sea-level change is essentially at the stage of data collection with explanation being achieved via inductive models. Studies of sea-level change lack any accepted formal methodology and therefore scientific laws and theories. Problems arise when a common language is required so that classification of and correlation between the work of different research workers can be made. Without adequately rigid operational definitions, and strict adherence to them, even statistically significant features become incomparable. The philosophical principles of sea-level studies are further weakened by the lack of an explicit statement of the working hypotheses which are to be tested and perhaps falsified. Multiple hypotheses should be presented so that research designs will lead to new data which will allow all but one working hypothesis to be rejected. Each working hypotheses must be presented in a form that allows for it to be tested and rejected.

The problems of sea level methodology are discussed within the context of comparing sea level chronologies from the estuaries of the North Sea. The need for a common language and rigid operational definitions is illustrated using examples of the use and misuse of basic terms: regression, transgression, lagoonal sediment, mean sea level, sea-level change. The utility of the method of multiple working hypotheses is presented in the discussion of the similarities and differences between the sea-level chronologies of various North Sea estuaries with the role of offshore barriers, in particular, critically examined.

*) Address of the author: Dr. I. Shennan, University of Durham, Department of Geography, South Road, Durham, United Kingdom DH 13 LE. 


\section{References}

Shennan, I. (1982): Problems of correlating Flandrian sea-level changes and climate. - In: Harding, A. F. (ed.), Climatic change in later prehistory: 52-67; Edinburgh (University Press).

- (1983): Flandrian and Late Devensian sea-level changes and coastal movements in England and Wales. - In: Sмтт, D. E. \& Dawson, A. G. (eds.), Shorelines and Isostasy: 255-283; London, New York (Academic Press).

-, Tooley, M. J., Davis, M. J. \& Haggart, B. A. (1983): Analysis and interpretation of Holocene sea-level data. - Nature, 302: 404-406; Basingstoke.

Papers in preparation: „Flandrian sea-level changes in the Fenland"

"Global analysis and correlation of sea-level data" (for Devoy, R. J. (ed.) Sea Surface Studies: A Global View)

Manuscript accepted on 2. 8. 1984 